blue-bottles. I cut an ounce of raw veal into dice, and dropped it in the bottom of the jar in a heap. He did not seem to see or smell it, but after a while happened to dive into it. He appeared to be full of joy at the discovery. One fragment after another he took in his hands, held it closely to his jaws, and sucked it dry by strong pulls. At each pull I could mark the receding red juice of the meat. When the veal was reduced to a pale fibre, he let it go and took a fresh bit. He always retired to the shelter of the paper to eat, with the sole exception of the mouthful he made of the mosquito. Like the King of Dahomey, he would not eat in public.

Fulton, Mo., Feb. 26 JULIA MCNAIR WRIGHT.

\section{Cold and Warm Waves}

THE observations taken at the meteorological establishment on the Eiffel Tower in Paris have led to several most interesting results ; and among otber things it has recently been found that the velocity of the air during an ordinary strong wind is abont twice as high at the top of this tower as it is at its base. Such being the case, we should expect to find advancing cold or warm waves far ahead in upper regions of what they are closer to the earth's surface; and so they actually are found to be, as mentioned by Professer Hazen in your last issue, when he says that the temperature change at isolated mountain-peaks, as Mount Washington or Pike' Peak, occurs several hours earlier at their tops than at their bases, or when he says that high areas, etc., advance with a velocity double that of the surface air. These phenomena give us, therefore, a very instructive illustration or proof of the effect of the friction between the earth's surface and the air moving over it; and they confirm the old popular belief that weatherchanges are brought about by the wind, or, what amounts to the same thing, that the advance of cold and warm waves is entirely due to mechanical action, or displacement of the surface-air as a body, in conformity to such rules as I have set forth in my paper, "On the Cause of Trade. Winds" (Transactions of the American Society of Civil Engineers, vol. xxiii.), which paper also gives a very simple clew to the increased cold or heat in the border current of cold and warm waves.

Professor Hazen, however, does not appear to be acquainted with the important results of these observations at Paris, when he concludes that the changes in temperature and humidity of the air accompanying the adrance of these waves cannot be due to the wind, or are entirely independent of the motion of a mass of air, although he curiously enough states at the same time that a rapid motion of an advancing wave has a tendency to increase the wind, which seems contradictory.

Starting from these false premises, no wonder our meteorologist arrives at some most startling results. He finds that the moisture of the air is "removed," "eliminated," or, as he says elsewhere, "sucked out" of the air in less than no time by some mysterious agency or another which cannot as yet be accounted for. Storms are transported or transferred through the air without the airparticles being moved at all. Indeed, when it is considered that the literal meaning of the word "storm" is " violent agitation or commotion," or, in other words, "wind," he wants to tell us that when a wind blows, the air-particles don't move at all : it is all deception, and the storm is due to electric energy or something else. The professor's mistaken notion here is, however, precisely similar to the one I pointed out in my last letter, when I tried to explain the fallacy of the result he arrived at, - that condensation did not always take place when saturated air " got chilled." His ideas of the principles of motion seem to differ remarkably from those engineers are accustomed to go by.

Finally, an entirely different subject is brought up by him, and treated in the same mysterious manner: "A portion of the heat in our storms is due to a peculiar condition of the atrosphere which intercepts the heat of the sun, and this heat gradually works down from the upper atmosphere to the earth." Mightn't it be simpler to say that when the sun is prevented from warming the earth's surface, its heat is taken up by the clouds, and consequently, when the cloud-carrying layers are brought near the earth's surface, as we know they are towards rain, this heat is felt by as ?
Professor Hazen is a meteorologist without a theory; and, although it may be much easier to run down than to build up, no doubt he has done excellent service by constantly finding fault with others in just conformity to this negative standpoint; but, as the professor always seems so very anxious "to strike at the very heart of present theories of storm-generation," and this evidently in his strong point, I may recommend him to strike at the heart of a rain theory I some time ago had the honor of presenting to the American Society of Civil Engineers, and he may thereby possibly be able to prove that his notions of the principles of motion, etc., are more correct than those held and practised by the members of that distinguished body.

Brooklyn, N.Y., March 2.

Franz A. Velschow, C.E.

\section{The Piney Branch Indian Workshop.}

THE " Annual Report of the Curator of the Museum of Archæology, Philadelphia" (Vol. i. No. 1) contains a criticism of recent work done, and conclusions drawn, by Mr. W. H. Holmes of the Bureau of Ethnology at the Piney Branch Workshop, near Washington, D.C., and of Mr. Holmes's papers thereon (American Anthropologist of January and July, 1890), thast to the writer appears to do great injustice to Mr. Holmes.

In his report, Dr. Abbott, who has visited the site and obtained specimens therefrom through Mr. Holmes, says, "The enormous number of 'blocked out' implements have recently been held as conclusive evidence that such objects are to be considered as ' failures,' and, this being so, that similar objects found under any circumstances in this country are of like signification." To such conclusion the doctor dissents (p. 8).

Again he says, "While the position taken by Mr. Holmes and others as to the archæological significance of the Piney Branch deposits may be wholly correct, and stand the test of every objection, the inferences drawn are too sweeping, and have not necessarily the bearing upon the question of man's antiquity in America which he practically claims. The conditions under which rude paleolithic implements occur in the valley of the Delaware are wholly different. Here they are characteristic of a horizon; are so associated with a well-marked deposit, that by no verbal jugglery can they be relegated to 'incongrous association,' and so are adventitious" (p. 9).

And concluding, the doctor says, "On the other hand, to accept Mr. Holmes's conclusion, that all rude implements, howsoever and wheresoever found, are Indian 'failures,' is not merely to remove from the class of implements the so-called 'turtlebacks' of the Delaware valley, but to remove the paleolithic implements of Europe, Asia, and Africa from the prehistoric archæology of those continents."

Mr. Holmes is an officer of the Bureau of Ethnology, whose works on pottery, on the antiquities of the South-West, and on the Chiriquian objects, have familiarized his name to all students of American archæology as a most painstaking and careful investigator; and, had he taken the ground asserted, he would have laid himself open to the charge of want of due care in conducting a scientific work.

Thus it will be observed that Dr. Abbott first says the Piney Branch objects " have recently been held as conclusive evidence that such objects are to be considered as failures," and dissents from such conclusion. Again he says, "Whilst the position taken by Mr. Holmes and others" may be correct as to Piney Branch, the conclusions are too sweeping, and have not the bearing which he (Mr. Holmes) practically claims. And in conclusion, Dr. Abbott, while claiming that the discovery of paleolithic implements of the Delaware valley occurred under different conditions from those under which the implements at Piney Branch were found, says the Delaware valley implements "by no verbal jugglery can be relegated to " incongrous associations." " The report starts by saying that the Piney Branch objects " have been held," and, later on, by "Mr. Holmes and others." In the last part of the latter sentence in which "Mr. Holmes and others" occurs, the doctor, in specifying Mr. Holmes individually, saddles the latter with conclusions which began with "have been held," and then defends the paleoliths of the Delaware from being by "verbal 
jugglery" relegated to "incongrous association;" the last part of the report saying, "To accept Mr. Holmes's conclusions, that all rude implements, howsoever and wheresoever found, not only removes the turtle-back of the Delaware valley, but removes the paleolithic implements of Europe, Asia, and Africa from the prehistoric archæology of those continents." In reading the curator's report of the Museum of Archæology relating to Mr. Holmes's work at Piney Branch, and the curator's views thereon, in connection with Mr. Holmes's papers in the American Anthropologist referring to this work, I was greatly surprised to find that Dr. Abbott's opinion and conclusions differed so widely from the conclusions which I had drawn from a tolerably careful examination of Mr. Holmes's work while excavating, from a careful reading of his papers, and from what I knew to be his ideas on the subject.

Mr. Holmes, under the direction of the Bureau of Ethnology, dug trenches into the hill at Piney Branch in order to develop the aboriginal workshop on the site. His papers in the American Anthropologist are simply an expression of what was developed in the trenches. In the January number of the American Anthropologist (1890) his plates of his work are as perfect as art can represent such work, or science could desire it should be represented. The objects found scattered throughout the "shop," from the surface to the cobbles in their original position, demonstrated beyond contradiction that the whole "shop" from end to end, from surface to bed, contained one class of work. Objects identical in material, shape, and manipulation, are found throughout the valley of the Potomac; and I have hundreds of similar specimens from the Patapsco, and South River in Maryland. The shape and work are not distinguishable from those of the paleolith of Europe ; and many persons around Washington concluded that our turtle-back, or possibly, better, the double turtle-back, was of the paleolithic age. The Piney Branch shop demonstrated that on that site probably millions of stones had been worked; that those stones were identical with the finds of the Potomac and its vicinity. This is accepted by all as beyond contradiction. Of the shop, Mr. Holmes (American Anthropologist, July, 1890, p. 224) says, "A hundred or a thousand years may have passed since the discontinuance of work upon this site. In the Delaware valley all the necessary elements of a time record exist, and there at least the record has been at least partly read." In the American Anthropologist (January, 1890, p. 14) Mr. Holmes says, "It causes me almost a pang of regret at having been forced to the conclusion that the familiar turtle-back or one-faced stone, the double turtle-back or two-faced stone, together with all similar rude shapes, must, so far as this site is concerned, be dropped wholly and forever from the category of implements." Further, Mr. Holmes, in the same paper (p. 23), says, "Many of the rude implements of the Seine - assigned to a great antiquity and to an unknown race - are nearly identical with our quarry forms. On the Thames the analogues of nearly all classes of rude implements are found in the high, level gravels, thus carrying history back with certainty to remote ages. In the Delaware valley the rudest forms, corresponding to our failure shapes, are obtained from our glacial gravels, and the less rude varieties occur in more recent formations or under conditions that seem to make them safe indices of the steps of progress. In the Potomac valley, on the other hand, all the rude forms, appear to be but failures, or unfinished pieces representing stages in the manufacture of arrow and spear points of the Indian." In conclusion (p. 26) Mr. Holmes says that he is ready to modify any of his statements, conclusions, or inferences, when the facts are found to warrant the change.

If Dr. Abbott can in any place quote Mr. Holmes as either saying, or even intimating, as suggested in his report, by "verbal jugglery" or otherwise, that Mr. Holmes claims that the Piney Branch shop has any bearing "on man's antiquity in America;" or if the curator of the American Museum of Archæology can justify his remarks, "that to accept Mr. Holmes's conclusions, that all rude implements, howsoever and wheresoever found, is not merely to remove the 'turtle-back' of the Delaware valley, but to remove the paleolithic implements of Europe, Asia, and Africa from the prehistoric archæology of those continents," - I am willing to stand corrected. If, on the other hand, the doctor fails to show that any such theory has been advanced by $\mathrm{Mr}$. Holmes, such as attributed to him, the doctor will have to admit, that, as the representative of the institution of which he is curator, he has been as unfortunate in his remarks as unwarranted in his assertions.

Nowhere that I can find has Mr. Holmes made any such assertion as attributed to him. On the contrary, he has strictly con fined himself to the character of the work he had in hand, and has demonstrated that the so-called "turtle-back" was not paleolithic in the Potomac valley and its vicinity; and this demonstration has generally been accepted as conclusive so far as it applies to such objects on the field mentioned. He carefully leaves the paleolith to its proper sphere, as a matter which those who have studied and examined have described as being found "in the high level gravels, thus carrying history back to remote ages." To the Delaware valley finds Mr. Holmes accords a probable antiquity that is creditable to him as a liberal judge. There are in my own collection many surface finds from Anne Arundel County, Md., that are so similar to implements found by Dr. Abbott at Trenton, that an impartial judge might question even the great age of the Trenton implements without laying himself open to the charge of an effort to remove the paleolithic age of any country from the realms of " prehistoric archæology."

Notwithstanding the vast amount of valuable work performed by archæologists in America within the last twenty years, archæ-. ology may yet be considered in its infancy: and, while fair criticism should be courted by those making archæological investigations, attributing to an investigator thoughts and notions never advanced by him might be considered as verbal jugglery. New theories are too often advanced, and new implements too often described, the originators of which are frequently the first to repudiate them; and every branch of archæology opens too broad a field for archæologists to have to lay the institutions which they represent open to severe criticism in order to strengthen a pet theory.

J. D. MCGUIRE.

Ellicott City, Md., March 2.

\section{Anthropoid Heads in Stone from Oregon.}

I HAVE seen the pamphlet of Mr. Terry, describing the anthropoid heads in stone from Columbia River, Oregon. The author offers two suggestions as to their origin. One supposes the existence in former years of anthropoid apes in this region. Professor Marsh, who owns one of the stone heads, could tell us whether any apes or monkeys are known to have existed there. I do not remember to have seen any literature on that subject. The second supposition is, that the people who made the stone heads once dwelt in lands abounding in apes. This is very much more probable. There are many species of anthropoid apes in western Asia, and there is nothing improbable in the hypothesis that the fabricator of the heads, or his ancestors, drew their inspiration from across the Pacific.

If Mr. Terry will allow me, I would suggest that he has omitted a more plausible explanation than either of the foregoing. From Sitka to northern California is the richest timber-belt in the world. The natives of all stocks have depended on the cedar and other trees for house, furniture, clothing, vessels, boats, tools of many kinds, and art materials. They knew how to fell the largest tree, and to divide it into planks and puncheons by means of numerous wedges and stone mauls. These mauls are very abundant in collections. I have seen them in the American Museum, where Mr. Terry's collection is installed. Most of them are carved or pecked into the form of animal heads. The material, heavy eyebrows, round bulging eyes, prominent cheeks, are all identical with the Terry specimens; only, in these, the lower part of the face is apelike. This is easily accounted for.

The Indians of this region are the most imitative creatures in the world. There are in the National Museum from this very Columbia region, and northward to Puget Sound, collected by Wilkes in 1838, carvings, in wood, bone, and stone, of dogs hitched to boats, steamboats with side-wheels, stoves with pipes and cowls on top, wagons, gates on hinges, glass windows, shingle roofs on houses, and, on a totem post, a missionary stealing two Indian 